\title{
EARNINGS MANAGEMENT INDUCED BY COGNITIVE REFERENCE POINTS
}

\author{
Van Caneghem $T$. \\ University of Antwerp
}

\begin{abstract}
Previous studies [Carslaw (1988), Thomas (1989) and Niskanen and Keloharju (2000)] have shown that companies' managers tend to round up the first digits of reported earnings (i.e. for companies reporting profits). According to Carslaw (1988), this type of behaviour is inspired by the existence of the so-called " $\$ 1.99$ " phenomenon where a price of $\$ 1.99$ is perceived as being abnormally lower than one of $\$ 2.00$. In the current study, we try to determine whether managers of U.K. listed companies also engage in this type of 'earnings rounding-up behaviour'. Analogous to the earlier studies, our study compares observed and expected (i.e. estimated using Benford's Law) frequencies for the second-from-the-left digit in reported earnings. Our results suggest that managers of U.K. listed companies tend to round up reported pre-tax income, in a way that increases the first digit by one, when they are faced with a nine in the second-from-the-left position for this particular earnings measure. The major contribution of the current study is that it introduces discretionary accruals in this line of research. Discretionary accruals were estimated using both the Jones model (1991) and the modified Jones model as proposed by Dechow, Sloan and Sweeney (1995). Our results clearly suggest that discretionary accruals are used in order to round up reported earnings figures. Moreover, discretionary accruals enabled us to increase the power of the tests used in previous studies.
\end{abstract}

\section{INTRODUCTION}

Several studies [e.g. Burgstahler and Dichev (1997), Degeorge, Patel and Zeckhauser (1999) and Gore, Pope and Singh (2001)] have demonstrated that earnings are managed in order to meet targets or thresholds. Typically, the following targets are aimed for: (1) report positive earnings (i.e. loss aversion); (2) sustain recent performance (i.e. report a higher earnings figure than last year); and (3) meet analysts' expectations. Several explanations for 
this threshold-induced behaviour exist. According to Degeorge, Patel and Zeckhauser (1999), this type of earnings management is inspired by the fact that stakeholders (e.g. potential investors) use "rules of thumb" (e.g. the aforementioned thresholds) for the evaluation of firms' performance. Consequently, not meeting targets may be very costly (e.g. a decline in the value of the firm's shares). Moreover, it is possible that managers' compensation (e.g. the allowance of a bonus) is linked to meeting certain targets (e.g. the aforementioned thresholds). Numerous studies [e.g. Healy (1985), Gaver, Gaver and Austin (1995), Holthausen, Larcker and Sloan (1995) and Guidry, Leone and Rock (1999)] have shown that such earningsbased bonus plans might induce earnings management.

Loss aversion is inspired by the important psychological difference that exists between positive and negative earnings figures (Degeorge, Patel and Zeckhauser, 1999). Due to the latter, a profit of 500 GBP will be perceived as abnormally larger than a loss of 1,000 GBP. As a result of a quite similar psychological effect, an earnings figure of 5 million GBP will be perceived as abnormally larger than an earnings figure of 4,998,500 GBP, whereas the difference only amounts to a marginal 1,500 GBP in both cases. The latter effect might be explained by the fact that users of financial statements use so-called 'cognitive reference points' (i.e. they will summarize earnings figures as follows: $\mathrm{N} * 10^{\mathrm{k}}$, where $\mathrm{N}=$ the first digit of the earnings figure) to evaluate firms' performance (Niskanen and Keloharju, 2000). In view of this, Carslaw (1988), Thomas (1989) and Niskanen and Keloharju (2000) investigated whether managers tend to round up the first digits of their reported earnings in an attempt to influence perceptions of financial statement users. In general, results obtained in these studies suggested this type of behaviour. The aim of the present study is to investigate this type of behaviour for a sample of U.K. listed companies. Moreover, we introduce discretionary accruals (henceforth DACC), a popular proxy for earnings management in the literature, in this type of study in an attempt to (1) determine to what extent DACC are used to round up earnings; and (2) increase the power of the tests used in the previous studies. 
The remainder of the paper is organized as follows. In Section 2, we give a brief overview of the previous literature on the phenomenon of earnings enhancement. The hypotheses development and the sample selection procedures are discussed in Section 3. In Section 4, the empirical results are provided. Conclusions are presented in Section 5.

\section{PREVIOUS LITERATURE}

Carslaw (1988) was the first to investigate whether managers round up the first digits of their reported earnings. The expectations of Carslaw for this type of behaviour were based on: (1) psychological studies that have shown that humans use numbers that are multiples of ten to evaluate and compare figures (see introduction); and (2) the existence of the "\$1.99" phenomenon [i.e. "A price of $\$ 1.99$ is perceived to be abnormally lower to a customer than one of $\$ 2.00$." (Carslaw, 1988: 321)]. Both phenomena are induced by the fact that humans have only a limited amount of memory available and therefore only store the most important bits of information (i.e. the first digits of a large number). This led Carslaw to believe that managers might benefit from rounding up the first digits of reported earnings, given the expectation that users of financial statements will place most emphasis on the first digits of earnings figures. Therefore, Carslaw predicted an abnormal distribution for the second-from-the-left digit (henceforth second digit) of reported earnings. Specifically, Carslaw predicted "(...) an abnormally low occurrence of high digits in the second place of numbers and a compensating abnormally high frequency of lower digits in order that the number just exceeds the major reference point." (Carslaw, 1988: 322). Based on a sample of New-Zealand companies, Carslaw found results consistent with his expectations [i.e. significantly more (fewer) zeros (nines) as second digit in reported earnings than would normally be expected]. Company years for which a loss was reported were eliminated because Carslaw did not expect the same pattern to be observed for loss observations. 
Thomas (1989) extended the paper of Carslaw (1988) in several ways: (1) he used a sample of U.S. data (i.e. in order to check whether the results obtained by Carslaw could be generalized); (2) he did not eliminate loss observations; and (3) he also performed the analysis on quarterly earnings. In general, results for positive annual earnings were in line with the results obtained by Carslaw [i.e. Thomas also found a significantly higher (lower) than expected incidence of zeros (nines) in the second position]. Results based on negative annual earnings showed an inverse pattern [i.e. a statistically significant higher (lower) than expected occurrence of nines (zeros) in the second position]. Both aforementioned patterns were also found to exist for quarterly earnings, albeit with smaller deviations from expected frequencies.

Niskanen and Keloharju (2000) performed a third study on this empirical matter by examining this type of behaviour for a sample of Finnish companies. This study is in fact an additional check on the validity of the results obtained in the aforementioned studies in that it searches for income-increasing behaviour in an institutional setting that encourages income-decreasing earnings management. The latter can be explained by the very close link that exists between reported accounting earnings and corporate taxable income for Finnish companies (Niskanen and Keloharju, 2000). The results obtained in this study are again supportive of roundingup behaviour. Particularly strange about the results obtained by Niskanen and Keloharju is that they differ from the results obtained in the two aforementioned studies in at least two ways: (1) Niskanen and Keloharju found significantly fewer sixes and sevens as second digit than would be expected in a random sample, whereas no statistically significant anomalies in frequencies were noted for eights and nines; and (2) they reported a statistically significant higher incidence of both zeros and ones as second digit than would normally be expected. In other words, the results of Niskanen and Keloharju suggest that Finnish companies go even further when it comes to the enhancement of earnings figures and that they do not limit themselves to rounding up nines into zeros. The latter is not consistent with ex ante expectations based on the Finnish institutional setting. 


\section{RESEARCH DESIGN}

\subsection{Hypotheses Development}

Similar to Carslaw (1988), Thomas (1989) and Niskanen and Keloharju (2000), we predict a higher (lower) than expected incidence of low (high) digits in the second position for reported earnings, inspired by earnings enhancement (i.e. in the current study we will solely focus on positive earnings figures). Therefore, we test the following hypothesis:

H1: There will be an abnormally higher (lower) than expected occurrence of low (high) digits in the second position for reported earnings.

To the extent that observed abnormal frequencies of certain digits as second digit in reported earnings are really due to earnings enhancement, elimination of these 'enhancements' should result in the elimination of the observed abnormalities. Earnings enhancement can be considered as a specific form of earnings management and therefore DACC (i.e. a popular proxy for earnings management in the literature) will be used to eliminate these enhancements from reported earnings. Earnings management can then be defined as “(..) a purposeful intervention in the external financial reporting process, with the intent of obtaining some private gain (...)" (Schipper, 1989: 92). It has to be clear that we solely focus on pure financial reporting decisions that fall within GAAP (i.e. discretionary accounting choices), which clearly differ from both financial statement fraud and real operating decisions (e.g. the timing of an asset sale) (Peasnell et al., 2000). We focus on the former because it is obvious that pure financial reporting decisions are more flexible when it comes to rounding up reported earnings, which clearly takes place after the closing date of the accounting year. It is important to acknowledge that DACC are not only used to round up earnings figures. The following earnings management incentives are 
typically investigated in the literature: (1) earnings-based compensation plans (see Section 1); (2) (binding) accounting-based debt covenants [Healy and Palepu (1990) and DeFond and Jiambalvo (1994)]; (3) earnings thresholds (see Section 1); (4) political costs [Daley and Vigeland (1983) and Cahan (1992)]; (5) fierce trade union activity [Liberty and Zimmerman (1986), DeAngelo and DeAngelo (1991), Mautz and Richardson (1992) and Konings, Labro and Roodhooft (1998)]; (6) taxation [Scholes, Wilson and Wolfson (1992), Guenther (1994), Maydew (1997), Roubi and Richardson (1998) and Yin and Cheng (2000)]; and (7) executive changes [Strong and Meyer (1987), DeAngelo (1988) and Pourciau (1993)]. Consequently, the elimination of DACC from companies' reported earnings will not only result in the elimination of rounding-up behaviour. Given the nature of earnings enhancement, we consider it to be most likely that DACC are, at first, set in view of the aforementioned incentives and that the resulting earnings figure is then rounded up by means of an additional correction to DACC. Based on these considerations, we do expect that observed abnormalities in the distribution of certain digits, as second digit in reported earnings, will no longer occur when considering earnings before DACC (henceforth EBDACC). The elimination of earnings management should clear out all observed anomalies with regard to digital frequencies. Thus,

H2: No abnormal pattern in the frequencies of second digits will be found for EBDACC.

\subsection{Sample Selection}

All accounting data used in the present study were obtained from the Worldscope section of Bureau van Dijk's Global Researcher CD-rom, which contains financial statement data for companies that are listed on a stock exchange. From this database we selected all U.K. companies. All financial institutions were eliminated from the sample due to the fact that the estimation of DACC is problematic for these firms. We limited our sample to earnings figures for the accounting year 1998 and eliminated all companies: (1) that reported a loss for this particular accounting year [as mentioned 
before, Thomas (1989) evidenced that these companies avoid reporting round earnings figures]; and (2) for which earnings figures were composed of only one digit. From the growing body of earnings management literature, it is not clear which earnings measure managers try to enhance. Therefore, we decided to investigate several earnings measures for the aforementioned type of manipulation: (1) operating income; (2) net income before extraordinary items; (3) earnings before interest and taxes; and (4) pre-tax income.

\subsection{Measuring DACC}

We used both the Jones model (1991) and the modified Jones model as proposed by Dechow, Sloan and Sweeney (1995) to estimate DACC. In fact, both models estimate non-discretionary accruals (henceforth NDACC) and then subtract them from total accruals (henceforth TACC) in order to arrive at the amount of discretionary accruals.

The Jones model estimates NDACC in the following manner:

$$
\mathrm{NDACC}_{\mathrm{T}}=\alpha_{1}\left(1 / \mathrm{A}_{\mathrm{T}-1}\right)+\alpha_{2}\left(\Delta \mathrm{REV}_{\mathrm{T}}\right)+\alpha_{3}\left(\mathrm{PPE}_{\mathrm{T}}\right)
$$

where

$\mathrm{T} \quad=$ the event year;

NDACC $\quad=$ NDACC scaled by lagged total assets;

A $\quad=$ total assets;

$\triangle \mathrm{REV} \quad=$ change in revenues scaled by lagged total assets;

$\mathrm{PPE} \quad=$ gross property, plant and equipment scaled by lagged total assets; and

$\alpha_{1}, \alpha_{2}, \alpha_{3} \quad=$ firm-specific parameters.

Estimates of the firm-specific parameters $\alpha_{1}, \alpha_{2}$ and $\alpha_{3}$ are generated using the following model in the estimation period:

$$
\mathrm{TACC}_{\mathrm{t}}=\mathrm{a}_{1}\left(1 / \mathrm{A}_{\mathrm{t}-1}\right)+\mathrm{a}_{2}(\Delta \mathrm{REV} t)+\mathrm{a}_{3}\left(\mathrm{PPE}_{\mathrm{t}}\right)+\mathrm{v}_{\mathrm{t}}
$$


where

$\mathrm{t} \quad=1,2, \ldots, 6$ (year of the estimation period);

TACC $=$ TACC scaled by lagged total assets; and

$\mathrm{a}_{1}, \mathrm{a}_{2}, \mathrm{a}_{3}=$ OLS estimates of $\alpha_{1}, \alpha_{2}$ and $\alpha_{3}$.

Total accruals are estimated as a function of the change in revenues and the level of property, plant and equipment. Both variables were introduced in order to control for changes in the firm's economic conditions. The change in revenues controls for changes in working capital accounts (which is part of total accruals) and property, plant and equipment controls for non-discretionary depreciation expenses. (DeFond and Subramanyam, 1998)

The modified Jones model differs from the original Jones model in that the change in revenues is adjusted for the change in receivables (i.e. only in the event period). Dechow, Sloan and Sweeney (1995) motivate their correction as follows: "... based on the reasoning that it is easier to manage earnings by exercising discretion over the recognition of revenue on credit sales than it is to manage earnings by exercising discretion over the recognition of revenue on cash sales." (Dechow, Sloan and Sweeney, 1995: 198).

\subsection{Estimating Expected Frequencies for Second Digits}

Analogous to Carslaw (1988), Thomas (1989) and Niskanen and Keloharju (2000), expected frequencies for the second digit in reported earnings were estimated using Benford's Law ${ }^{i}$ and the normalised Z-statistic was used to evaluate the significance of differences noted between actual and expected frequencies (see Table 1 and Table 2). Contradictory to what one might logically expect, the occurrence of each digit, as second digit in a particular number, is not equally likely. Zeros (nines) are most (least) likely to be 
observed as second digit by chance (see Table 1). This is referred to as Benford's Law.

An extensive study on the frequencies of digits in both the first and second position in lists of numbers led to Benford's Law. Based on several datasets (total number of observations $=23,197$ ) and the use of integral calculus, Benford developed formulas to estimate expected frequencies of first digits, second digits and digit combinations in lists of numbers. The law applies to lists of numbers that describe the relative sizes of similar phenomena (i.e. if these numbers are not influenced by human thought). (Nigrini and Mittermaier, 1997)

\section{RESULTS}

The anomaly in the frequencies of both low and high digits in the second position was only found to exist for pre-tax income in our sample of companies. All other earnings measures investigated in the current study did not show the irregularity searched for. It has to be noted that both earnings before interest and taxes and operating income showed a significantly lower than expected incidence of nines as second digit (statistically significant at the $5 \%$ level in both cases). However, the latter was not supported by a compensating (statistically significant) higher than expected occurrence of zeros in the second position. Therefore, only results for pre-tax income will be reported here (see Table 1) and the remainder of the study will focus on that particular earnings measure.

TABLE 1: The frequency of the second digits of U.K. listed companies' pre-tax income.

\begin{tabular}{|cccccc|}
\hline Digit & $\begin{array}{c}\text { Observed } \\
\text { Frequency }\end{array}$ & $\begin{array}{c}\text { Percentage of } \\
\text { All } \\
\text { Observations }\end{array}$ & $\begin{array}{c}\text { Expected } \\
\text { Percentage of } \\
\text { All } \\
\text { Observations }\end{array}$ & $\begin{array}{c}\text { Percentage } \\
\text { Deviation from } \\
\text { Expected } \\
\text { Frequency }\end{array}$ & Z-Value \\
\hline \hline 0 & 177 & 15.9 & 12.0 & 3.9 & 3.92 \\
1 & 133 & 11.9 & 11.4 & 0.5 & 0.50 \\
2 & 118 & 10.6 & 10.9 & -0.3 & -0.40 \\
\hline
\end{tabular}




\begin{tabular}{|c|c|c|c|c|c|}
\hline 3 & 119 & 10.7 & 10.4 & 0.3 & 0.24 \\
\hline 4 & 112 & 10.0 & 10.0 & 0.0 & -0.01 \\
\hline 5 & 101 & 9.0 & 9.7 & -0.7 & -0.78 \\
\hline 6 & 94 & 8.4 & 9.3 & -0.9 & -1.06 \\
\hline 7 & 91 & 8.1 & 9.0 & -0.9 & -1.04 \\
\hline 8 & 100 & 9.0 & 8.8 & 0.2 & 0.14 \\
\hline 9 & 71 & 6.4 & 8.5 & -2.1 & $-2.61 *$ \\
\hline
\end{tabular}

Table 1 clearly indicates a statistically significant higher (lower) than expected incidence of zeros (nines) as second digit in our sample companies' pre-tax income. The table shows that zeros (nines) occur 3.9 (2.1) percentage points more (less) often than would be expected based on Benford's Law. Two important conclusions can be drawn from these results. Firstly, Benford's Law does not apply to our sample companies' pre-tax income, which can be considered as an indication of earnings management. Earnings that are not influenced by human thought (i.e. unmanaged) should follow Benford's Law. Secondly, the obtained results seem to indicate that sample companies tend to round up pre-tax income, in a way that increases the first digit by one, when they are faced with a nine as second digit in this particular earnings measure. In general, results are consistent with $\mathrm{H} 1$ and are very similar to the results obtained by Carslaw (1987) and Thomas (1988). An alternative explanation for the obtained results might be that they are driven by the mere existence of accounting rules, which can be considered as an influence of human thought in the process of generating reported earnings. The elimination of DACC from reported earnings (i.e. tests of H2) may shed some light on this and will therefore result in more powerful tests.

Due to missing data, required for the estimation of DACC (see section 3.3), we had to eliminate several companies from our original sample. This resulted in a reduced sample of 624 companies, whereas the original sample consisted of 1,116 companies. An additional analysis was performed in order to check whether $\mathrm{H} 1$ held for our reduced sample. The results 
obtained for the reduced sample were very similar to the ones obtained for the original sample: (1) 2.4 (2.4) percentage points more (fewer) zeros (nines) were noted as second digit in companies' pre-tax income than would normally be expected based on Benford's Law (statistically significant at the $5 \%$ level in both cases); and (2) no other statistically significant differences were noted between actual and expected frequencies.

In order to test H2, EBDACC (i.e. pre-tax income before DACC) had to be calculated. Both DACC as estimated by the original and the modified Jones model were used for this purpose. Then, the frequencies of second digits were analysed for both EBDACC measures. Both measures generated similar results and therefore only those obtained for EBDACC based on the Jones model will be discussed in full. These results are presented in Table 2.

Table 2 clearly shows that the anomaly in the frequencies of second digits does no longer hold when DACC are eliminated from companies' pre-tax incomes. No statistically significant (i.e. at the conventional levels) differences were noted between actual and expected frequencies of second digits for EBDACC. Two important conclusions can be drawn from these results. Firstly, after the elimination of earnings management (i.e. DACC) earnings do follow Benford's Law. Therefore, results are consistent with H2 and suggest that the anomalies, which were noted under $\mathrm{H} 1$, are not driven by the existence of accounting rules. Secondly, the fact that EBDACC do not show more (fewer) zeros (nines) in the second position, than would be expected based on Benford's Law, suggests that companies tend to round up their earnings by means of DACC.

TABLE 2: The frequency of the second digits of U.K. listed companies' pre-tax income before DACC (Jones model).

\begin{tabular}{|c|c|c|c|c|c|}
\hline Digit & $\begin{array}{l}\text { Observed } \\
\text { Frequency }\end{array}$ & $\begin{array}{c}\text { Percentage of } \\
\text { All } \\
\text { Observations }\end{array}$ & $\begin{array}{c}\text { Expected } \\
\text { Percentage of } \\
\text { All } \\
\text { Observations }\end{array}$ & $\begin{array}{c}\text { Percentage } \\
\text { Deviation from } \\
\text { Expected } \\
\text { Frequency }\end{array}$ & Z-Value \\
\hline$\overline{0}$ & $\overline{772}$ & 111.5 & 12.0 & -0.5 & -0.42 \\
\hline
\end{tabular}




\begin{tabular}{|rrrrrr|}
1 & 72 & 11.5 & 11.4 & 0.1 & 0.05 \\
2 & 55 & 8.9 & 10.9 & -2.0 & -1.74 \\
3 & 70 & 11.2 & 10.4 & 0.8 & 0.60 \\
4 & 70 & 11.2 & 10.0 & 1.2 & 0.95 \\
5 & 58 & 9.3 & 9.7 & -0.4 & -0.41 \\
6 & 62 & 9.9 & 9.3 & 0.6 & 0.48 \\
7 & 46 & 7.4 & 9.0 & -1.6 & -1.49 \\
8 & 58 & 9.3 & 8.8 & 0.5 & 0.37 \\
9 & 61 & 9.8 & 8.5 & 1.3 & 1.07 \\
\hline
\end{tabular}

$\mathrm{N}=624$.

\section{CONCLUSION}

The main conclusions and contributions of the current study can be summarized as follows. Firstly, we document the existence of 'earnings rounding-up behaviour' for a sample of U.K. companies. The results presented in this study indicate that managers of U.K. listed companies tend to round up their reported pre-tax income, in a way that increases the first digit by one, when they are faced with a nine in the second position for this particular earnings measure. This finding is consistent with results obtained in other studies for other countries [Carslaw (1988) and Thomas (1989)]. Other earnings measures were included in our study, but the aforementioned pattern was only found to exist for companies' reported pretax incomes. Secondly, we demonstrate that companies' managers use $\mathrm{DACC}$ in order to round up their reported earnings figures.

\section{REFERENCES}

Burgstahler, D. and Dichev, I. (1997). Earnings Management to Avoid Earnings Decreases and Losses, Journal of Accounting and Economics, Vol. 24, pp. 99-126.

Cahan, S.F. (1992). The Effect of Antitrust Investigations on Discretionary Accruals: A Refined Test of the Political-Cost Hypothesis, The Accounting Review, Vol. 67, pp. 77-95. 
Carslaw, C.A.P.N. (1988). Anomalies in Income Numbers: Evidence of Goal Oriented Behavior, The Accounting Review, Vol. 63, pp. 321-327.

Daley, L.A. and Vigeland, R.L. (1983). The Effects of Debt Covenants and Political Costs on the Choice of Accounting Methods, Journal of Accounting and Economics, Vol. 5, pp. 195-211.

DeAngelo, L.E. (1988). Managerial Competition, Information Costs and Corporate Governance: The Use of Accounting Performance Measures in Proxy Contests, Journal of Accounting and Economics, Vol. 10, pp. 3-36.

DeAngelo, H. and DeAngelo, L. (1991). Union Negotiations and Corporate Policy: A Study of Labour Concessions in the Domestic Steel Industry During the 1980s, Journal of Financial Economics, Vol. 30, pp. 3-43.

Dechow, P.M., Sloan, R.G. and Sweeney, A.P. (1995). Detecting Earnings Management, The Accounting Review, Vol. 70, pp. 193-225.

DeFond, M.L. and Jiambalvo, J. (1994). Debt Covenant Violation and Manipulation of Accruals, Journal of Accounting and Economics, Vol. 17, pp. 145-176.

DeFond, M.L. and Subramanyam, K.R. (1998). Auditor Changes and Discretionary Accruals, Journal of Accounting and Economics, Vol. 25, pp. 35-67.

Degeorge, F., Patel, J. and Zeckhauser, R. (1999). Earnings Management to Exceed Thresholds, The Journal of Business, Vol. 72, pp. 1-33.

Gaver, J.J., Gaver, K.M. and Austin, J.R. (1995). Additional Evidence on Bonus Plans and Income Management, Journal of Accounting and Economics, Vol. 19, pp. 3-28.

Gore, P., Pope, P.F. and Singh, A.K. (2001). Discretionary Accruals and the Distribution of Earnings Relative to Targets, Working Paper, Lancaster University.

Guenther, D.A. (1994). Earnings Management in Response to Corporate Tax Rate Changes: Evidence from the 1986 Tax Reform Act, The Accounting Review, Vol. 69, pp. 230-243.

Guidry, F., Leone, A.J. and Rock, S. (1999). Earnings-Based Bonus Plans and Earnings Management by Business-Unit Managers, Journal of Accounting and Economics, Vol. 26, pp. 113-142.

Healy, P.M. (1985). The Effect of Bonus Schemes on Accounting Decisions, Journal of Accounting and Economics, Vol. 7, pp. 85-107.

Healy, P.M. and Palepu, K.G. (1990). Effectiveness of Accounting-Based Dividend Covenants, Journal of Accounting and Economics, Vol. 12, pp. 97123. 
Holthausen, R.W., Larcker, D.F. and Sloan, R.G. (1995). Annual Bonus Schemes and the Manipulation of Earnings, Journal of Accounting and Economics, Vol. 19, pp. 29-74.

Jones, J. (1991). Earnings Management During Import Relief Investigations, Journal of Accounting Research, Vol. 29, pp. 193-228.

Konings, J., Labro, E. and Roodhooft, F. (1998). Earnings Management and Trade Union Activity: Results for Belgium, Working Paper, University of Louvain.

Liberty, S.E. and Zimmerman, J.L. (1986). Labour Union Contract Negotiations and Accounting Choices, The Accounting Review, Vol. 61, pp. 692-712.

Mautz, R.D. and Richardson, F.M. (1992). Employer Financial Information and Wage Bargaining: Issues and Evidence, Labour Studies Journal, Vol. 17, pp. 35-52.

Maydew, E.L. (1997). Tax-Induced Earnings Management by Firms with Net Operating Losses, Journal of Accounting Research, Vol. 35, pp. 83-96.

Nigrini, M.J. and Mittermaier, L.J. (1997). The Use of Benford's Law as an Aid in Analytical Procedures, Auditing: A Journal of Practice \& Theory, Vol. 16 , pp. $52-67$.

Niskanen, J. and Keloharju, M. (2000). Earnings Cosmetics in a Tax-Driven Accounting Environment: Evidence from Finnish Public Firms, The European Accounting Review, Vol. 9, pp. 443-452.

Peasnell, K.V., Pope, P.F. and Young, S. (2000). Accrual Management to Meet Earnings Targets: UK Evidence Pre- and Post-Cadbury, British Accounting Review, Vol. 32, pp. 415-445.

Pourciau, S. (1993). Earnings Management and Nonroutine Executive Changes, Journal of Accounting and Economics, Vol. 16, pp. 317-336.

Roubi, R.R. and Richardson, A.W. (1998). Managing Discretionary Accruals in Response to Reductions in Corporate Tax Rates in Canada, Malaysia and Singapore, The International Journal of Accounting, Vol. 33, pp. 455-467.

Schipper, K. (1989). Commentary on Earnings Management, Accounting Horizons, Vol. 3, 91-102.

Scholes, M.S., Wilson, G.P. and Wolfson, M.A. (1992). Firms' Responses to Anticipated Reductions in Tax Rates: The Tax Reform Act of 1986, Journal of Accounting Research, Vol. 30, pp. 161-185. 
Strong, J.S. and Meyer, J.R. (1987). Asset Writedowns: Managerial Incentives and Security Returns, The Journal of Finance, Vol. 20, pp. 643663.

Thomas, J.K. (1989). Unusual Patterns in Reported Earnings, The Accounting Review, Vol. 64, pp. 773-787.

Yin, Q.J. and Cheng, C.S.A. (2000). Earnings Management of Profit Firms and Loss Firms in Response to the Tax Rate Reduction, Working Paper.

\section{ENDNOTES}

i Benford's Law states that the probability of $y$ being the second digit of a particular number can be estimated as follows: $\quad \sum_{x=1}^{9}\left(\log _{10}\left(x+\frac{y+1}{10}\right)-\log _{10}\left(x+\frac{y}{10}\right)\right)$ with $x$ being the first digit of that particular number. 